\title{
The effect of previous visual experience upon the response to depth in domestic chickens ${ }^{1}$
}

\author{
LESTER KRAMES AND W. J. CARR
} TEMPLE UNIVERSITY

Performance on a visual cliff was observed in 84 domestic chicks reared in one of three conditions. Ss reared in nests with opaque walls and transparent floors, affording a view of a textured surface located $1 \mathrm{ft}$ below, were most likely to descend during testing. Ss reared in nests with opaque floors and transparent walls, affording a view of the same textured surface, did not differ from $S$ s reared with opaque walls and floors.

In spite of intensive investigation (e. g., Walk \& Gibson, 1961; Shinkman, 1963; Walk, 1965), the effect of previous visual experience upon an animal's response to a potential falling-off place is incompletely understood. For example, Emlen (1963) showed that young herring gulls reared in nests situated on cliffs were less likely to descend from a visual cliff than were gulls reared in nests located on plateaus. On the other hand, Tallarico \& Farrell (1964) reported that domestic chicks reared from hatching over the deep surface of a visual cliff were more likely to descend to the deep surface during testing than were chicks reared on the shallow surface. Thus, in the first experiment, previous experience with depth inhibited the bird's descent, but in the second experiment it facilitated it.

The apparently conflicting findings reported by Emlen and by Tallarico and Farrell may be due to genetic differences between herring gulls and domestic chickens. Alternatively, they may be due to differences in the optical nature of the vantage point from which the birds viewed the deep surface. Emlen's cliff-reared birds viewed a deep surface by looking over the edge of an opaque nest; Tallarico and Farrell's birds received their experience by looking directly through the transparent floor of the rearing site. The present experiment was designed to test this latter hypothesis. Subjects

The Ss were 84 domestic chicks (DeKalb No. 131) of undetermined sex, which were obtained as eggs from a commercial hatchery after 18 days of incubation. The Ss were hatched and allowed to dry off for $2-3 \mathrm{~h}$ in a darkened laboratory incubator. By random assignment, Ss were then transferred to one of three rearing environments, where they remained in groups of three or four Ss each for 34-36 h, at which time they were tested on a modified visual cliff. Prior to testing, Ss received no food or water. Apparatus and Procedure

Twenty-five Ss were reared in containers with opaque walls and floors (shallow-reared). Thirty Ss were reared in containers with opaque walls and transparent floors (deep-reared), and 29 Ss had transparent walls and opaque floors (cliff-reared).

The containers housing all Ss were made of heavy cellophane and fashioned into tubes which measured 6 in. in diameter and 12 in. in height. The tubes stood upright upon a surface which consisted of a large double thickness of glass, situated $12 \mathrm{in.} \mathrm{above}$ the floor of the room. That part of the floor which was potentially visible to Ss was covered with heavy oilcloth, possessing a design of red and white checks, each measuring 0.75 in. square.

The cellophane walls of the containers housing the shallow-reared Ss were painted flat gray, and a piece of the checkered oilcloth was sandwiched between the two thicknesses of glass forming an opaque floor. For the deep-reared Ss, the walls of the containers were also painted gray, but the floors remained transparent. For the cliff-reared Ss, the walls were transparent and the floors opaque. In order to eliminate extraneous stimulation (e.g., people moving about in the room), each container housing cliff-reared Ss was surrounded by a large cardboard enclosure located approximately 18 in. away from the container. The opaque walls of the containers housing the other two groups made similar enclosures unnecessary. The Ss in all three groups could look out the tops of their containers and see the ceiling of the room, which was painted flat gray. An arrangement of incandescent lamps provided illumination which was approximately equal for all three experimental groups.

Thus, both the deep- and cliff-reared Ss could view the floor of the room, located 12 in. below their containers, the former by looking directly through the transparent floors and the latter by looking over the edge of the opaque floors through the transparent walls. The $\mathrm{Ss}$ in the shallow-reared environment could not see the floor of the room. Note that the shallow- and deep-reared environments approximated the conditions used by Tallarico and Farrell, while the shallow- and cliff-reared environments approximated those used by Emlen.

The Ss were tested on a modified visual cliff. It consisted of a plate of glass measuring $4 \mathrm{ft}$ square, in the center of which was located a circular platform. The platform was 6 in. in diameter and 1 in. high; it was covered with the same checkered oilcloth used in the rearing environment. The plate of glass was suspended 12 in. above the floor of the room, and that part of the floor which was visible from the 
Table 1. Percentage of Ss Descending Within $15 \mathrm{~min}$ and Mean Latency of Descent.

\begin{tabular}{lccc} 
Rearing Condition & N & $\begin{array}{c}\text { Percentage } \\
\text { Descending }\end{array}$ & $\begin{array}{c}\text { Mean Latency } \\
\text { (in sec) }\end{array}$ \\
\hline Shallow-Reared & 25 & 24.0 & 184.3 \\
Deep-Reared & 30 & 73.3 & 350.0 \\
Cliff-Reared & 29 & 41.4 & 220.8 \\
\hline
\end{tabular}

platform was covered with the oilcloth. The illuminating conditions approximated those of the rearing environment, and the lights were placed so as to minimize the amount of reflectance from the glass plate. Thus, when placed upon the platform, $S$ was confronted with a situation closely resembling a falling-off place which was 13 in. high. In order to eliminate extraneous stimulation, the entire apparatus was surrounded by a large cardboard enclosure. The E observed $S$ through a small peep hole.

At the time of testing, each $S$ was removed individually from the rearing environment and placed in the center of the platform, facing away from $E$. The $S$ was removed from the apparatus as soon as it descended (i.e., placed both feet on the glass) or after $15 \mathrm{~min}$ had elapsed. The latencies of descent were recorded.

\section{Results and Discussion}

Table 1 shows the percentage of Ss descending and the mean latency of descent for each of the three experimental groups. Overall differences among the observed percentages of Ss descending were statistically significant $\left(x^{2}=14.00, d f=2, p<.001\right)$. Further, the percentage of birds descending among the deepreared Ss was significantly greater than that among the cliff-reared Ss $\left(X^{2}=4.92, \mathrm{df}=1, \mathrm{p}<.05\right)$ and among the shallow-reared Ss $\left(X^{2}=12.50, \mathrm{df}=1, \mathrm{p}<.01\right)$. However, the cliff- and shallow-reared Ss did not differ significantly. Further, the three groups did not differ significantly with respect to the mean latency of descent.
The present findings confirm those reported by Tallarico \& Farrell (1964), who showed that chickens reared on the deep side of a visual cliff are more likely to descend to the deep side during testing than are birds reared on the shallow side. Therefore, one may conclude that the response of chickens to a potential falling-off place can be modified by previous visual experience. A similar effect has been reported in rats (Kaess \& Wilson, 1964; Carr \& McGuigan, 1965).

However, the present findings also suggest that the response of chickens to a potential falling-off place depends upon the nature of their previous experience with depth. Chickens which gain their experience from a vantage point which provides optical support (i.e., the cliff-reared environment) are less likely to descend from a cliff than are birds which gain their experience from a vantage point which does not provide optical support (i.e., the deep-reared environment).

\section{References}

CARR, W. J., \& McGUIGAN, D. I. The stimulus basis and modification of visual cliff performance in the rat. Anim. Behav., 1965, 13, 25-29.

EMLEN, J. T. Determinants of cliff edge and escape responses in herring gull chicks. Behaviour, 1963, 22, 1-15.

KAESS, D. W., \& WILSON, J. P. Modification of the rat's avoidance of visual depth. J. comp. physiol. Psychol., 1964, 58, 151-152.

SHINKMAN, P. G. Visual depth discrimination in day-old chicks. $J$. comp. physiol. Psychol., 1963, 56, 410-414.

TALLARICO, R. B., \& FARRELL, W. W. Studies of visual depth perception: An effect of early experience on chicks on the visual cliff. J. comp. physiol. Psychol., 1964, 57, 94-96.

WALK, R. D. The study of visual depth and distance perception. In D. S. Lehrman, R. A. Hinde, and E. Shaw (Eds.), Advances in the study of behavior. Vol. 1. New York: Academic Press, 1965, pp. 100-154.

WALK, R. D., \& GIBSON, ELEANOR J. A comparative and analytical study of visual depth perception. Psychol. Monogr., 1961, 75, (15, Whole No. 519).

\section{Note}

1. This article is based upon a thesis submitted by the senior author in partial fulfillment of the requirements for the $M$. A. degree at Temple University. The research was supported by a grant from the T. L. Bolton Trust Fund. Portions of this paper were presented at the meeting of the American Association for the Advancement of Science, New York, December, 1967 